International Journal of Osteoarchaeology

Int. J. Osteoarchaeol. 12: 4-11 (2002)

DOI: $10.1002 /$ oa. 608

\title{
Isotopic Tracking of Prehistoric Pinniped Foraging and Distribution Along the Central California Coast: Preliminary Results
}

\author{
R. K. BURTON ${ }^{a}$, D. GIFFORD-GONZALEZ ${ }^{\text {b,* }}$, J. J. SNODGRASS ${ }^{c}$ AND \\ P. L. KOCH ${ }^{\mathbf{d}}$ \\ a Department of Ornithology and Mammalogy, Moss Landing Marine Laboratories, Moss \\ Landing, CA 95039 \\ ${ }^{\mathrm{b}}$ Department of Anthropology, University of California, Santa Cruz, CA 95064 \\ c Department of Anthropology, Northwestern University, Evanston, IL 60208 \\ a Department of Earth Sciences, University of California, Santa Cruz, CA 95064
}

ABSTRACT Zooarchaeological data from Monterey Bay and the adjacent central California coast corroborate earlier observations from northern California and Oregon that Callorhinus ursinus (northern fur seal) was a much more common component in prehistoric marine mammal prey than its present pelagic distribution and foraging habits would predict. C. ursinus remains from mid-Holocene Monterey Bay occurrences are predominantly from female individuals, associated with an inshore piscifauna, and lack associated artifactual evidence for deep water exploitation. Taken together with evidence from Oregon, this suggests that mid-Holocene $C$. ursinus populations had different foraging, resting, and, arguably, reproductive behaviours than historically reported. Currently debated is whether the contrast between prehistoric and present patterns of pinniped species representation results from: 1) late Holocene prehistoric resource depression by aboriginal hunters, 2) depredations of the early historic fur trade, or 3) non-anthropogenic climatic or oceanographic change. The issue has thus far been addressed with presence or absence data on pinniped species and age/sex classes in dated contexts. While these are fundamental data, they cannot shed light on the nature of foraging behaviour of the species in question, a key dimension of the problem. This paper reports a pilot study utilizing stable isotope analysis aimed to elucidate prehistoric pinniped foraging patterns, specifically that of $C$. ursinus. Elements from six archaeological sites in Monterey and Santa Cruz counties were analysed for stable isotope compositions of carbon and nitrogen in bone collagen and compared to a latitudinally ordered modern dataset. Results for archaeological $C$. ursinus strongly suggest that prehistoric animals habitually foraged at lower latitudes than characterize the species today, supporting earlier claims of their year-round residency south of Alaska. Copyright (c) 2002 John Wiley \& Sons, Ltd.

Key words: stable isotopes; distribution; pinnipeds; Callorhinus; California; bone collagen; zooarchaeology

\section{Introduction}

Pinnipeds have played an important role in coastal human ecology for thousands of years,

\footnotetext{
* Correspondence to: Dr Gifford-Gifford-Gonzalez, Dept of Anthropology, Social Sciences I, Univ. of California, Santa Cruz, CA 95064, USA. e-mail: dianegg@cats.ucsc.edu.
}

as a rich source of meat, fat, fur, and hides. Human-modified pinniped remains dating to over 40,000 years BP have been found in Middle Stone Age South African sites of Klasies River Mouth and Die Kelders Cave (Klein \& Cruz-Uribe, 1996). On the western coast of North America, pinniped remains are common in archaeological sites from the mid-Holocene 
onwards (Lyman, 1991; Hildebrandt \& Jones, 1992).

Among the most common of pinniped taxa in coastal Oregonian and Californian sites from the seventh through second millennia BP is Callorbinus ursinus (northern fur seal), a member of the family Otariidae. This species is highly sexually dimorphic, with females ranging from $35-60 \mathrm{k}$ and adult males from 185 to $275 \mathrm{k}$ (Gentry, 1998). This is seen osteologically in marked differences in skeletal robusticity, long bone lengths, and both cranial and post-cranial morphology.

Presently, C. ursinus ranges from coastal Japan to Alaska to California and breeding primarily occurs at the north end of the range on the Pribilof and Commander Islands, Alaska. Following the summer breeding season, adult males typically remain in the northern portion of the range and forage in offshore waters of the north Pacific and Bering Sea, while the adult females and juveniles of both sexes migrate as far as southern California $\left(\sim 30^{\circ} \mathrm{N}\right)$. Today, the species is highly pelagic, only coming ashore during the summer to form large densely packed rookeries (Gentry, 1998). Kajimura (1983) describes them as opportunistic feeders known to prey on over 60 species of fish (e.g., pollock and herring) and cephalopods (e.g., squid and octopus), and he reports that at lower latitudes they are most often found between 74 and $130 \mathrm{~km}$ offshore (Kajimura, 1980). The species' pelagic distribution appears to track highly productive upwelling zones along offshore continental slopes.

C. ursinus are not reported to haul out in large numbers anywhere on the mainland coast or on nearshore islands along California, Oregon, or Washington with two recent exceptions. A breeding population of C. ursinus was located on San Miguel Island off Southern California in the late 1960s (Peterson et al., 1968) and a small breeding colony has recently occupied the Farallon Islands west of San Francisco, California (Sydeman \& Allen, 1999).

\section{Contrasts in prehistoric to present pinniped abundances and distribution}

Comparison of present-day pinniped species' distribution and abundances off California with evidence from prehistoric archaeofaunas presents a stark contrast, in which C. ursinus especially has a strikingly different profile in its ubiquity and pattern of occurrence. One way to illustrate this contrast is by assessing how likely it would be that elements of a given species would find their way into littoral deposits by attritional mortality processes operating today, which along the California and Oregon coasts exclude concerted human predation. We have used data from the Marine Mammal Stranding Network (National Marine Fisheries Service, 1998) on frequency of strandings by pinniped species along the California coast between 1990 and 1997 (Table 1). Zalopbus californianus (California sea lion) was by far the most commonly encountered species, accounting for $57 \%$ of all reported strandings. Phoca vitulina, (harbour seal), and Mirounga angustirostris (northern elephant seal), each accounted for $16 \%$ of the sample. By contrast, C. ursinus accounted for only $1 \%$ of species-identified strandings (Figure 1).

Archaeofaunas from central coastal California testify that $C$. ursinus is consistently among the most common pinniped species (Table 2). For example, from the six sites in our pilot study, $C$. ursinus specimens comprise $30 \%$ of the sample, a remarkable difference from frequencies in both modern stranding data and population surveys (Figure 1). These data refine those reported by Hildebrandt \& Jones (1992) for northern California and by Lyman $(1989,1991)$ for Oregon, where $C$. ursinus remains are common amongst eared seal specimens (but often less numerous than Eumetopias jubatus, the Steller sea lion).

Table 1. California pinniped strandings reported to the California Marine Mammal Stranding Network, 1990-1997 (Data from National Marine Fisheries Service, 1998)

\begin{tabular}{lrr}
\hline Taxon & $\begin{array}{c}\text { Number of } \\
\text { Strandings }\end{array}$ & $\begin{array}{c}\text { Frequency } \\
(\%)\end{array}$ \\
\hline Arctocephalus townsendi & 13 & $<1$ \\
Callorhinus ursinus & 153 & 1 \\
Eumetopias jubatus & 56 & $<1$ \\
Zalophus californianus & 7993 & 57 \\
Mirounga angustirostris & 2190 & 16 \\
Phoca vitulina & 2235 & 16 \\
Unidentified Pinnipedia & 1269 & 9 \\
Unidentified Otariidae & 2 & $<1$ \\
Unidentified Phocidae & 2 & $<1$ \\
Total & 13,913 & 100 \\
\hline
\end{tabular}

Int. J. Osteoarchaeol. 12: 4-11 (2002) 


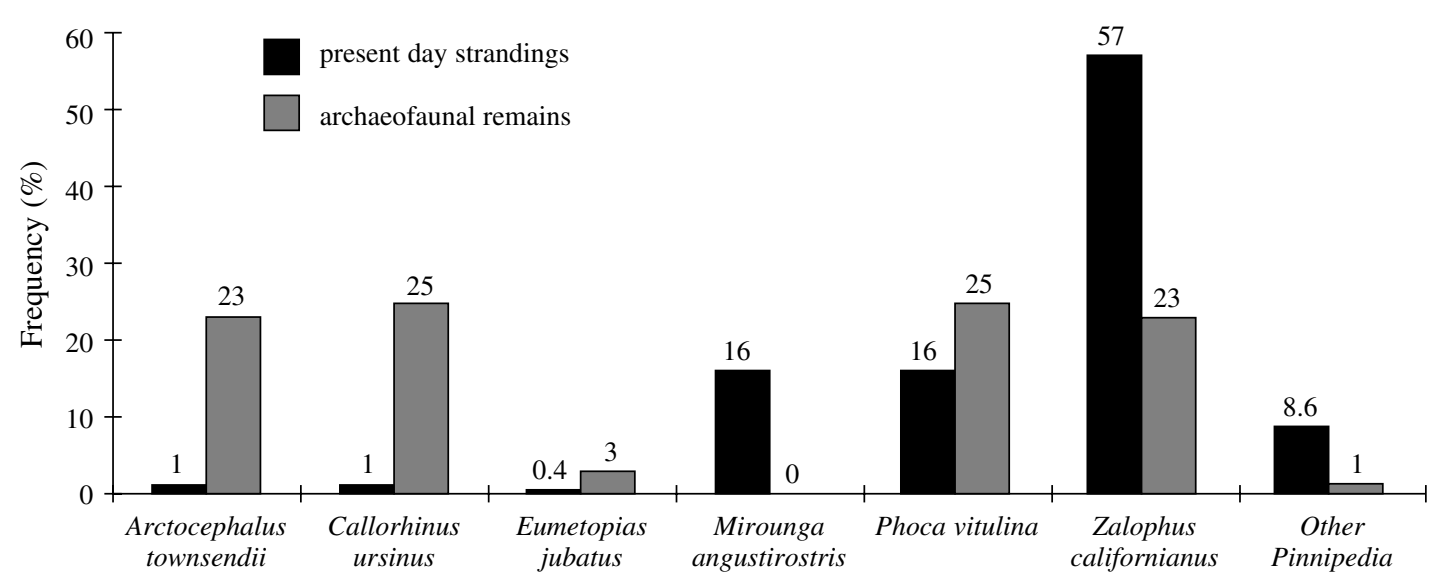

Figure 1. Comparison of present-day pinniped species' stranding frequencies along California, quantified as number of identifiable individuals of each taxon, with evidence from prehistoric archaeofaunas, quantified as number of identifiable specimens (NISP) for each taxon (see also Tables 1 and 2).

Table 2. Occurrence of archaeofaunal pinniped remains at six prehistoric sites excavated along coastal Monterey and Santa Cruz counties, California, quantified as number of identifiable specimens (NISP) for each taxon. Sources: CA-Scr-18 (Gifford, 1978; Jones, 1993; Milliken, 1993), CA-Scr-35 (Gifford \& Marshall, 1984; Jones, 1993; Milliken, 1993), CA-Mnt-170 (Breschini \& Haversat, 1980), CA-Mnt-228 (Jones et al., 1992), CA-Mnt-229 (Dietz et al., 1988); Jones \& Jones (1992), and CA-Mnt-1570 (Jones et al., 1992)

\begin{tabular}{|c|c|c|c|c|c|c|}
\hline Site & $\begin{array}{c}\text { Arctocephalus } \\
\text { townsendi }\end{array}$ & $\begin{array}{c}\text { Callorhinus } \\
\text { ursinus }\end{array}$ & $\begin{array}{c}\text { Eumetopias } \\
\text { jubatus }\end{array}$ & $\begin{array}{c}\text { Zalophus } \\
\text { californianus }\end{array}$ & $\begin{array}{l}\text { Phoca } \\
\text { vitulina }\end{array}$ & $\begin{array}{l}\text { Otariidae } \\
\text { Indet }\end{array}$ \\
\hline CA-SCr-18 Middle Period c. $2600-800$ rybp & 0 & 0 & 1 & 3 & 0 & 1 \\
\hline CA-SCr-35 Middle Period c. $2600-800$ rybp & 0 & 8 & 3 & 3 & 0 & 2 \\
\hline CA-Mnt-170 Early Period c. 5500-2600 rybp & 0 & 1 & 0 & 3 & 3 & 0 \\
\hline CA-Mnt-228 Upper component c. 1415-1635 rybp & 1 & 3 & 0 & 3 & 21 & 0 \\
\hline Totals & 2 & 34 & 4 & 32 & 34 & 9 \\
\hline
\end{tabular}

${ }^{1}$ Dating for this site is problematic, in that radiocarbon determinations on marine shell provide dates some 3500 years older than do obsidian hydration estimates from artifacts in the same strata. Excavators report the site strata are mixed (see referenced report).

\section{Debates over changes in pinniped abundances}

Archaeologists are currently debating how to explain the ubiquity of eared seals, including C. ursinus, in prehistoric sites and their nearabsence from the present-day coasts of Oregon and California. Both camps in this debate agree that it is highly likely that mainland or nearshore hauling-out sites existed along this stretch of Pacific coast in prehistoric times. This contrasts with the assertion by Minor and colleagues (1987) that the presence of C. ursinus in Oregon sites reflects a very early use of plank canoes and other

Copyright (C) 2002 John Wiley \& Sons, Ltd. technology for truly pelagic foraging (i.e., the ability to prey on C. ursinus in its present offshore habitat) by Native Americans. Lyman (1991), moreover, argues that archaeological evidence testifies to the presence of not only hauling-out sites but also rookeries used by $Z$. californianus, $E$. jubatus, and C. ursinus in Oregon, and that these were on the mainland or readily accessible from it without pelagic watercraft.

One position in the current debate, espoused by Hildebrandt \& Jones (1992; Jones \& Hildebrandt, 1995), asserts that prehistoric overpredation on pinniped colonies accounts for the differing species abundance profiles of past versus present, in an aboriginal "tragedy of the commons" 
scenario. They argue that exploitation of pinnipeds along the west coast of North America was initiated by early- and mid-Holocene inhabitants of the coastal region and that zooarchaeological remains from Oregon and California indicate a human-driven shift over time in taxonomic frequencies. Specifically, they argue that earlier sites (2000-6000 BP) have a predominance of "migratory" marine mammal species, which, by their enumeration comprise the otariid species $C$. ursinus, Z. californianus, Arctocephalus townsendi (southern fur seal), and E. jubatus. They argue that these otariid species were replaced in the latest prehistoric sites $(<1500 \mathrm{BP})$ by non-migratory species such as P. vitulina, and Enhydra lutris (sea otter), which would have been available year round but at relatively lower densities (Jones \& Hildebrandt, 1995).

Another position, held by Lyman $(1989,1991)$, asserts that archaeologically documented breeding colonies of $C$. ursinus and other eared seals were present in the region until extirpated during the historic period, largely by European and Euro-American fur-traders. Lyman (1991) begins his arguments by refuting the posited connection between specific types of technology such as harpoons and true deep-water hunting. He then documents the presence of adult male and neonate elements in addition to those of female C. ursinus in archaeofaunal samples from the Umpqua/Eden site, and neonates and female remains from the Seal Rock and Whale Cove sites, all on the Oregon coast. Lyman interprets the presence of neonates, today born primarily in the Alaska region, as compelling evidence for the existence of $C$. ursinus rookeries along the Oregon coast. Notably, dates for the occurrence of $C$. ursinus at the Oregon sites are predominantly in the last millennium BP.

Yet a third position, articulated by a number of researchers based in the Santa Barbara region, implicates mid-Holocene changes in climate and ocean upwelling patterns as a non-anthropogenic cause of the shift in pinniped species abundances from prehistoric to present (Glassow et al., 1988; Walker et al., 1989; Arnold, 1992a,1992b, Davenport et al., 1993). A very detailed record of Holocene palaeoenvironmental conditions exists for the Santa Barbara Channel area. The loss of eared seals from archaeological assemblages

Copyright @ 2002 John Wiley \& Sons, Ltd. would thus be explained primarily by collapse of the prey resources upon which these top-level consumers depend, rather than by exclusively human agency.

The databases for these three explanations themselves form a latitudinal gradient, which should be considered when assessing whether a one-size-fits-all scenario could be expected for some $1200 \mathrm{~km}$ of coastline.

To date, debates have employed frequency data on pinniped species and their age/sex classes in dated contexts. These data are essential, but they cannot directly shed light on the nature of these animal species' prehistoric foraging and reproductive behaviour, a key dimension of the problem. If, for example, C. ursinus were breeding at rookery sites on the Oregon coast, all age and sex classes capable of feeding themselves could be expected to forage in those latitudes over a substantial span of the summer months. Moreover, C. ursinus is known to be a flexible and opportunistic feeder (Kajimura, 1983). Thus, although it is presently a pelagic feeder off the Oregon and California coast, populations hauling out and breeding on that coast might have displayed more variations in nearshore versus offshore feeding strategies.

To elucidate pinniped foraging patterns, specifically that of $C$. ursinus, we have conducted a pilot study of stable isotope compositions, with the aim of distinguishing their role in this debate. We report here only the first steps in that direction, which involves investigating the nature of foraging patterns of prehistoric C. ursinus from the central California region, through measurements of the carbon and nitrogen isotope composition of bone collagen from archaeological specimens and comparison with values derived from modern pinniped populations.

Studies of terrestrial and marine animals have demonstrated that ratios of stable carbon isotopes $\left({ }^{13} \mathrm{C} /{ }^{12} \mathrm{C}\right)$ reflect the source of organic carbon fixed through photosynthesis at the base of a given food web. Ratios of stable nitrogen isotopes $\left({ }^{15} \mathrm{~N} /{ }^{14} \mathrm{~N}\right)$ reflect the trophic level at which an animal feeds. Whole-body isotope compositions are ${ }^{13} \mathrm{C}$-enriched by $\sim 1.0 \%$ relative to diet with each trophic step while ${ }^{15} \mathrm{~N}$-enrichment is $\sim 3.0 \%$ o (see review by Michener \& Schell, 1994). Different tissue types (e.g., lipid, collagen, hair, muscle) 
show different absolute fractionations relative to diet (DeNiro \& Epstein, 1978; Tieszen et al., 1983; Hobson et al., 1996) but ${ }^{13} \mathrm{C}$-enrichment of $\sim 1 \%$ o is also observed when single tissue types are examined at different trophic levels (Rau et al., 1983). Additionally, variations in carbon isotopes may reveal location (nearshore versus offshore) and latitudinal variations at which animals forage in the marine environment (Hobson et al., 1997; Burton \& Koch, 1999).

\section{Materials and methods}

Taxonomically diagnostic elements of three species, C. ursinus, P. vitulina, and Z. californianus, were chosen for isotopic analysis and comparison to values of present day populations of the same taxa. Archaeofaunal remains derive from six sites along the central California coast, in Monterey and Santa Cruz counties (Table 2). Two authors (DGG, JJS) reviewed prior taxonomic identifications for all pinniped bones available for the isotopic study. Each specimen was compared with museum reference materials from the Department of Ornithology and Mammalogy, California Academy of Sciences, San Francisco. Additionally, morphological and metric comparisons of all specimens used for isotopic analysis were made using data and drawings derived from present day comparative specimens from numerous museum collections (Snodgrass \& Gifford-Gonzalez, in prep.). One site inventory represented in Table 2, CA-Mnt-228, was not reanalysed, since the materials were unavailable at the time of this study and were therefore not used in our isotopic analysis. All materials are housed in the Archaeology Archives in the Department of Anthropology, University of California, Santa Cruz, and are curated by one of the authors (DGG). Although at the time of this pilot study, we were unable to radiometrically date pinniped bones used in the study, radiometric dates (when available), obsidian hydration, and artifactual typology strongly suggest that all sites antedate $\sim 600 \mathrm{BP}$ (Table 2 ).

Approximately 200-300 mg of compact bone was removed with a low-speed cutting tool from each of the C. ursinus $(\mathrm{n}=8), P$. vitulina $(\mathrm{n}=12)$, and $Z$. californianus $(\mathrm{n}=10)$ specimens. Samples were cleaned of bulk organic material and

Copyright (C) 2002 John Wiley \& Sons, Ltd. cancellous bone was removed to reduce the risk of analysing diagenetically or chemically altered tissue. Bone fragments were demineralized by soaking in $0.5 \mathrm{~N} \mathrm{HCl}$ for $24 \mathrm{~h}$ at $4{ }^{\circ} \mathrm{C}$, lipids were extracted using a chloroform/methanol technique (Bligh \& Dyer, 1959), and humic acid contaminants were removed with a $1.0 \mathrm{M}$ sodium hydroxide wash. Samples were dried and placed in Sn foil boats, then analysed using a Carlo-Erba elemental analyser interfaced with a Micromass Optima gas source stable isotope mass spectrometer at the Department of Earth Sciences, University of California, Santa Cruz. The standard deviation for repeated measurements of a gelatin standard was $<0.12 \%$ o for both carbon and nitrogen. Results are expressed as:

$\delta^{13} \mathrm{C}$ or $\delta^{15} \mathrm{~N}=\left[\left(\mathrm{R}_{\text {sample }} / \mathrm{R}_{\text {standard }}\right)-1\right] \times 1000$

where $\mathrm{R}_{\text {sample }}$ and $\mathrm{R}_{\text {standard }}$ are the ratios of ${ }^{13} \mathrm{C} /{ }^{12} \mathrm{C}$ or ${ }^{15} \mathrm{~N} /{ }^{14} \mathrm{~N}$ for the sample and the standard. The standards are Pee Dee Belemnite limestone for carbon and atmospheric $\mathrm{N}_{2}$ for nitrogen, and the units are parts per thousand (\%o).

Isotopic results from archaeofaunal samples were compared with values from a prior baseline study of values from modern pinniped populations (Burton \& Koch, 1999).

\section{Isotopic results}

Carbon nitrogen ratios calculated for prehistoric bone collagen samples $($ mean $=3.24$, sd $=0.04$ ) are in excellent agreement with ratios calculated from modern pinniped bone collagen (mean = 3.24, sd $=0.13$; Burton \& Koch, 1999). This confirms that the prehistoric bone collagen we analysed is pristine and has not undergone significant diagenetic or chemical alteration.

A summary of our isotopic results is presented in Table 3. Mean $\delta^{13} \mathrm{C}$ values of prehistoric bone collagen are lowest for C. ursinus $(-13.3 \%$ ) and highest for $P$. vitulina $(-11.5 \%)$. Mean values for $Z$. californianus fell between these end members $\left(-12.9 \%\right.$ ) . A similar pattern is revealed by $\delta^{15} \mathrm{~N}$ values. C. ursinus values are highest (18.6\%o) while $P$. vitulina values are lowest $(18.1 \%$ ) with $Z$. californianus falling in between (18.2\%o). Variations in isotopic composition among these groups are 
Table 3. $\delta^{13} \mathrm{C}$ and $\delta^{15} \mathrm{~N}$ values of bone collagen from archaeofaunal pinniped remains from six prehistoric sites excavated along coastal Monterey and Santa Cruz counties, California and values from studies of modern pinnipeds from Alaska and central California (Data from Burton \& Koch, 1999). Foraging locations and latitude of archaeological specimens are inferred

\begin{tabular}{|c|c|c|c|c|c|}
\hline Species & $\begin{array}{c}\text { \# of } \\
\text { Samples }\end{array}$ & $\begin{array}{c}\text { Mean } \delta^{13} \mathrm{C} \pm \\
\text { S.D. }\end{array}$ & $\begin{array}{c}\text { Mean } \delta^{15} \mathrm{~N} \pm \\
\text { S.D. }\end{array}$ & $\begin{array}{l}\text { Foraging } \\
\text { Location }\end{array}$ & $\begin{array}{l}\text { Foraging } \\
\text { Latitude }\end{array}$ \\
\hline \multicolumn{6}{|l|}{ Archaeological specimens } \\
\hline Callorhinus ursinus & 8 & $-13.3 \% \circ \pm 0.3$ & $18.6 \%$ \pm 0.8 & [Offshore] & [Middle] \\
\hline Phoca vitulina & 12 & $-11.5 \%$ \pm 0.3 & $18.1 \%$ \pm 0.3 & [Nearshore] & [Middle] \\
\hline Zalophus californianus & 10 & $-12.9 \%$ \pm 0.4 & $18.2 \% \circ \pm 0.7$ & [Nearshore] & [Low-Middle] \\
\hline \multicolumn{6}{|c|}{ Modern specimens from central California } \\
\hline Phoca vitulina & 18 & $-12.4 \%$ \pm 0.6 & $18.7 \% \circ \pm 1.0$ & Nearshore & Middle \\
\hline Zalophus californianus & 15 & $-13.8 \% \circ \pm 1.1$ & $18.6 \%$ \pm 0.9 & Nearshore & Low-Middle \\
\hline Mirounga angustirostris (female) & 14 & $-14.4 \%$ \pm 0.8 & $18.1 \%$ \pm 1.3 & Offshore & Middle \\
\hline Mirounga angustirostris (male) & 10 & $-13.6 \%$ \pm 1.1 & $18.2 \% \circ \pm 0.7$ & Nearshore & Middle-High \\
\hline \multicolumn{6}{|l|}{ Modern specimens from Alaska } \\
\hline Callorhinus ursinus (female) & 10 & $-14.8 \%$ \pm 0.7 & $16.6 \% \pm 1.4$ & Offshore & High-Middle \\
\hline Callorhinus ursinus (male) & 9 & $-15.4 \% \circ \pm 0.9$ & $16.5 \% \circ \pm 1.4^{1}$ & Offshore & High \\
\hline Phoca vitulina & 37 & $-13.7 \%$ \pm 1.0 & $17.4 \%$ \pm 1.8 & Nearshore & High \\
\hline
\end{tabular}

${ }^{1}$ Value was incorrectly published in Burton \& Koch (1999).

highly statistically significant for carbon (one factor ANOVA, $\mathrm{P}<0.001)$, but not for nitrogen $(\mathrm{P}=0.235)$

Comparison of isotope compositions of present day pinnipeds to prehistoric populations reveals substantial differences (Table 3) (Burton \& Koch, 1999). The $\delta^{13} \mathrm{C}$ values of present day $P$. vitulina from California are on average $0.9 \%{ }^{13} \mathrm{C}$ depleted when compared to prehistoric samples. Likewise, comparison of present day $\delta^{13} \mathrm{C}$ values of $Z$. californianus to those of prehistoric animals reveals the same offset. On the other hand, contemporary C. ursinus are on average ${ }^{13} \mathrm{C}$ depleted by $1.8 \%$ relative to those from the past. Differences in $\delta^{13} \mathrm{C}$ values of present day versus prehistoric samples of C. ursinus, P. vitulina, and $Z$. californianus are highly significant (one-factor ANOVA, $\mathrm{P}<0.001$ ). Likewise, differences in $\delta^{15} \mathrm{~N}$ values between these same groups are highly significant $(\mathrm{P}<0.001)$.

\section{Discussion}

Differences between present day and prehistoric $P$. vitulina and $Z$. californianus $\delta^{13} \mathrm{C}$ values are in close agreement with shifts in the isotopic composition of atmospheric $\mathrm{CO}_{2}$ attributed to fossil fuel combustion and biomass destruction over the past 200 years. The $\delta^{13} \mathrm{C}$ records of tree rings from the same period indicate a $0.8 \%$ o

Copyright (c) 2002 John Wiley \& Sons, Ltd.
${ }^{13} \mathrm{C}$-depletion in the isotopic composition of atmospheric $\mathrm{CO}_{2}$ (Stuiver et al., 1984). Measurements of the carbon isotope composition of $\mathrm{CO}_{2}$ from the Siple Station Antarctic ice core reveals a similar ${ }^{13} \mathrm{C}$-depletion of about $1.1 \%$ over the last 80 to 100 years (Freidl et al., 1986). We thus attribute the $0.9 \%$ o difference between $\delta^{13} \mathrm{C}$ values of present day and prehistoric populations of $P$. vitulina and of $Z$. californianus to this anthropogenic alteration of the carbon isotopic composition of the atmosphere.

By contrast, the difference between prehistoric and present day $\delta^{13} \mathrm{C}$ values for $C$. ursinus is much greater and cannot be attributed solely to anthropogenic factors. Burton \& Koch (1999) found when comparing either the nearshore or the offshore marine environment, that variations in latitude are reflected in carbon isotope ratios. They also found that $\delta^{15} \mathrm{~N}$ values tended to be lower in animals from higher latitudes $(16.6-18.1 \%$ ) than for those occurring at middle latitudes $\left(18.1-18.9 \%\right.$ ). The $\delta^{13} \mathrm{C}$ values of prehistoric C. ursinus $(-13.3 \%$ o) if corrected by $-0.9 \%$ (to ameliorate anthropogenic affects on the isotopic composition of the atmosphere) are very similar to those of present day female $M$. angustirostris $(-14.4 \% 0)$, a middle latitude offshore forager (Burton \& Koch, 1999). The $\delta^{15} \mathrm{~N}$ values of prehistoric C. ursinus (18.6\%o) are also well within the range of nitrogen ratios expected for 
middle latitude pinnipeds and are well above the range of those from high latitudes.

Measurements of the isotopic compositions of modern and archaeological samples suggest C. ursinus, or at least those found in these central California sites, was predominantly a middle latitude forager and thus a year-round resident of California and/or Oregon waters. This implies that C. ursinus was possibly also breeding in central California or at least within the latitudinal zones that produce this distinctive isotopic signature. This inference is congruent with Lyman's (1991) argument from the presence of newborn C. ursinus remains in coastal Oregon archaeological sites. If $C$. ursinus was breeding prehistorically along the coasts of central to northern California and Oregon, it is likely they would have been accessible to aboriginal hunter-gatherer populations in considerable abundances, given the species gregarious rookery habits.

Our isotopic study strongly suggests that $C$. ursinus, as a species encountered in waters off central California, has undergone a dramatic shift in its foraging and breeding behaviour between the time our samples accumulated and the present. However, our data cannot definitively address the three alternative scenarios posited in the literature for their decline in regional abundances. Clearly, it is necessary to directly date our samples to precisely determine the span of time over which the species was present in the region. Moreover, a concerted effort must be made to expand the sample to include sites spanning the late Holocene and to place the dated isotopic results within a broader palaeoenvironmental context. Nonetheless, this pilot study has established that latitudinal parameters of pinniped foraging patterns can be read from archaeological specimens using stable isotope analysis and thus provides a valuable tool for exploring these questions.

\section{Acknowledgements}

R. Burton was supported by an NSF Graduate Research Training Grant (NSF-EHR 9553614), D. Gifford-Gonzalez by a grant from the Social Sciences Division at UC Santa Cruz, and P. Koch by NSF-EAR 9725854. We thank L. Baptista, K.

Copyright (C) 2002 John Wiley \& Sons, Ltd.
Cebra, and D. Long of the California Academy of Sciences for access to comparative skeletal collections. We thank the following individuals for their assistance with this project: G. Breschini, D. Costa, W. Hildebrandt, T. Jones, R. Quinn, D. Steadman, J. Storå, and J. Zachos.

\section{References}

Arnold J. 1992a. Complex hunter-gatherer-fishers of prehistoric California: chiefs, specialists and maritime adaptations of the Channel Islands. American Antiquity 57: 60-84.

Arnold J. 1992b. Cultural disruption and the political economy in Channel Islands prehistory. In Essays on the Prebistory of Maritime California, Jones TL (ed.). Center for Archaeological Research, No. 10: Davis, CA; 129-144.

Bligh ES, Dyer WJ. 1959. A rapid method of total lipid extraction and purification. Canadian Journal of Biochemistry and Pbysiology 37: 911-917.

Breschini GS, Haversat T. 1980. Preliminary Archaeological Report and Arcbaeological Management Recommendations for CA-MNT-170, on Pescadero Point, Monterey County, California. Report on file at the Northwest Information Center of the California Archaeological Inventory, Sonoma State University.

Burton RK, Koch PL. 1999. Isotopic tracking of foraging and long distance migration in northeastern Pacific pinnipeds. Oecologia 1 19: 578-585.

Davenport D, Johnson JR, Timbrook J. 1993. The Chumash and the swordfish. Antiquity 67: 257-272.

DeNiro MJ, Epstein S. 1978. Influence of diet on the distribution of carbon isotopes in animals. Geocbimica et Cosmochimica Acta 42: 495-506

Dietz SA, Hildebrandt W, Jones T. 1988. Archaeological investigations at Elkhorn Slough: CA-MNT229: A Middle Period site on the central California coast. Papers in Northern California Antbropology; No. 3.

Freidl H, Lotscher H, Oeschger $\mathrm{H}$, Siegenthaler U, Sauffer B. 1986. Ice core record of ${ }^{13} \mathrm{C} /{ }^{12} \mathrm{C}$ ratio of atmospheric $\mathrm{CO}_{2}$ in the past two centuries. Nature 324: 237-238.

Gentry RL. 1998. Bebaviour and Ecology of the Northern Fur Seal. Princeton University Press: Princeton.

Gifford DP (ed.). 1978. Report on the Assemblage of CA-SCR-18, Lundberg Foundation Salvage, Davenport, California. Manuscript on file with the Archaeological Research Facility, University of California, Santa Cruz, and the Northwest Information Center of the California Archaeological Inventory, Sonoma State University; 75-78.

Int. J. Osteoarchaeol. 12: 4-11 (2002) 
Gifford DP, Marshall F. 1984. Analysis of the archaeological assemblage from CA-Scr-35 Santa Cruz County, California. Coyote Press Archives of Prebistory 2: $1-78$.

Glassow ML, Wilcoxon L, Erlandson J. 1988. Cultural and environmental change during the early period of Santa Barbara channel prehistory. In The Archaeology of Prebistoric Coastlines, Bailey G, Parkington J (eds). Cambridge University Press: New York; 64-77.

Hildebrandt WR, Jones TL. 1992. Evolution of marine mammal hunting: A view from the California and Oregon coasts. Journal of Anthropological Archaeology 11: 360-401

Hobson KA, Schell DM, Renouf D, Noseworthy E. 1996. Stable carbon and nitrogen isotopic fractionation between diet and tissues of captive seals: Implications for dietary reconstructions involving marine mammals. Canadian Journal of Fisheries and Aquatics Science 53: 528-533.

Hobson KA, Sease JL, Merrick RL, Piatt JF. 1997. Investigating trophic relationships of pinnipeds in Alaska and Washington using stable isotope ratios of nitrogen and carbon. Marine Mammal Science 13 : 114-132.

Jones TL. 1993. Evaluation of UCSC Archaeological Collections from Santa Cruz, Monterey, and San Luis Obispo Counties. Unpublished consultant's report on file in the UC Santa Cruz Archaeology Archives, University of California, Santa Cruz, CA 95064.

Jones TL, Hildebrandt WR. 1995. Reasserting a prehistoric tragedy of the commons. Journal of Anthropological Archaeology 14: 78-98.

Jones TL, Jones DA. 1992. Elkhorn Slough revisited: Reassessing the chronology of CA-MNT-229. Journal of California and Great Basin Anthropology 14(2): 159-179.

Jones TL, Van Buren T, Grantham S, Huddleson J, Fung T. 1992. Phase II Archaeological Investigations for the Castroville Bypass Project, Monterey County, California. Draft ms. on file, California Department of Transportation, Sacramento, California.

Kajimura H. 1980. Distribution and migration of northern fur seals (Callorbinus ursinus) in the eastern Pacific. In Further Analysis of Pelagic Fur Seal Data Collected by the United States and Canada During 1958-1974. Kajimura H, Lander RH, Perez MA, York AE, Bigg MA (eds). U.S. National Marine Fisheries Service: Seattle; 4-43.

Kajimura H. 1983. Opportunistic Feeding of the Northern Fur Seal, Callorbinus ursinus, in the Eastern Nortb Pacific Ocean and Eastern Bering Sea. U.S. Dept. of Commerce, NOAA Tech. Rep., NMFS SSRF-779.

Klein RG, Cruz-Uribe K. 1996. Exploitation of large bovids and seals at Middle and Later Stone Age sites in South Africa. Journal of Human Evolution 31: 315-334

Lyman RL. 1989. Seal and sea lion hunting: A zooarchaeological study from the southern northwest coast of North America. Journal of Antbropological Archaeology 8: 68-99.

Lyman RL. 1991. Prebistory of the Oregon Coast. Academic Press: San Diego.

Michener RH, Schell DM. 1994. Stable isotope ratios as tracers in marine aquatic food webs. In Stable Isotopes in Ecology and Environmental Science, Lajtha K, Michener RH (eds). Blackwell Scientific Publications: Boston, $138-157$.

Milliken R. 1993. Results of my September 15, 1993 Examination... Olivella sp. Beads and Haliotis sp. Artifacts... from SCr-42 (sic)... Unpublished consultant's report on file in the UC Santa Cruz Archaeology Archives, University of California, Santa Cruz, CA 95064.

Minor R, Toepel KA, Greenspan R. 1987. Archaeological Investigations in the Cape Perpetua Scenic Area, Central Oregon Coast. USDI Bureau of Land Management Cultural Resources Series, Portland Oregon; No. 1.

National Marine Fisheries Service (Southwest Region). 1998. Pinniped Strandings Reported to the California Marine Mammal Stranding Network (1990-1997). [Online]. Available: http://swr.ucsd.edu/psd/strandin.htm [1998 October 22].

Peterson RS, LeBoeuf BJ, DeLong RL. 1968. Fur seals from the Bering Sea breeding in California. Nature 219: 899-901.

Rau GH, Mearns AJ, Young DR, Olson RJ, Schafer HA, Kaplan IR. 1983. Animal ${ }^{13} \mathrm{C} /{ }^{12} \mathrm{C}$ correlates with trophic level in pelagic food webs. Ecology 64: 1314-1318

Stuiver M, Burk RL, Quay PD. 1984. ${ }^{13} \mathrm{C} /{ }^{12} \mathrm{C}$ ratios in tree rings and the transfer of biospheric carbon to the atmosphere. Journal of Geopbysical Research D. Atmospheres 89(7): 11731-11748.

Sydeman WJ, Allen SG. 1999. Pinniped population dynamics in central California: Correlations with sea surface temperature and upwelling indices. Marine Mammal Science 15: 446-461.

Tieszen LL, Boutton TW, Tesdahl KG, Slade NA. 1983. Fractionation and turnover of stable carbon isotopes in animals tissues: Implications for $\delta^{13} \mathrm{C}$ analysis of diet. Oecologia 57: 32-37.

Walker PL, DeNiro MJ, Lambert P. 1989. The effects of European contact on health of Alta California Indians. In Columbian Consequences, Volume I, Thomas DH (ed.). Smithsonian Institution Press: Washington, $\mathrm{DC}_{i}$ 349-364. 